\title{
The Norwegian Pentecostal Mission's work in Kenya between 1955 and 1984: A historical perspective
}

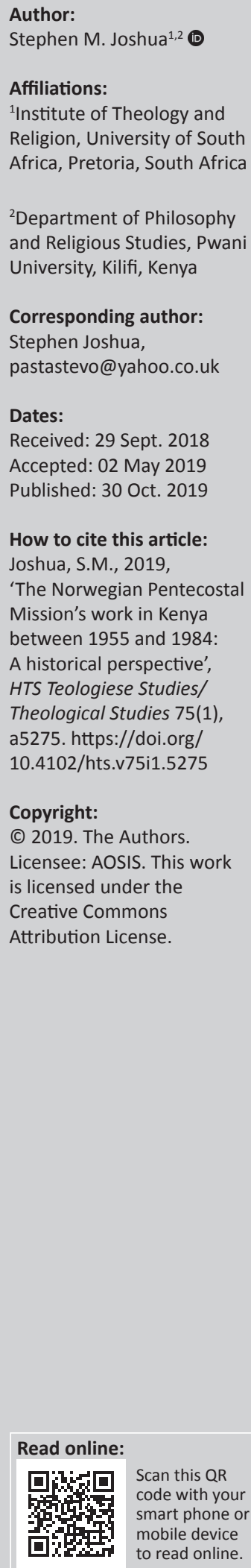

This article attempts to reconstruct an early history of the Norwegian Pentecostal Mission's (NPM) work in Kenya. The Free Pentecostal Church (FPC), known as the Free Pentecostal Fellowship in Kenya (FPFK) until April 2018, was born out of a 1984 merger between the Swedish Free Mission and the NPM. The Norwegians came earlier in 1955, whereas their Scandinavian counterparts arrived in 1960. The article contests that during the period under review, the first 29 years of NPM's presence in Kenya, the NPM was characterised by a fast-growing enthusiasm in establishing mission stations and local churches through evangelism and social work activities in education, medical care, orphanages, midwifery and compassionate handouts of commodities to villagers. These would be overtaken by the efforts to merge Swedish and Norwegian interests and establishments into one denomination in 1976 and the move towards nationalising the FPFK by handing over church leadership to the Kenyans by 1997. The article contests that the zeal and successes of the missionaries and local church workers in sowing the seeds of the gospel were checked by cultural and socio-economic setbacks in Kenya's colonial context as well as the nationalisation process. The increased presence of Norwegian missionaries in Kenya during the 1960s were largely motivated by, among other factors, the channelling of Norwegian government aid monies to foreign development regions through missionary agencies and the imminent independence of the East African state.

Keywords: Pentecostal; History; Scandinavia; Missions; Kenya.

\section{Introduction}

The Free Pentecostal Fellowship in Kenya (FPFK) is a local church registered in Kenya since 1977 (FPFK 2002:13). In April 2018, the church adopted a new constitution and changed its name to Free Pentecostal Church (FPC) during its Annual General Meeting (AGM) held in Karen Christian College in Nairobi (FPFK 2013:6). The church has over 170000 members and about 500 local churches that are organised into 28 regions spread all over the country (FPFK 2013:14-19). The FPFK church owes its origin to Scandinavian missionary work in East Africa. Two missionary societies, the Swedish Free Mission (SFM), which later changed its name to Evangelical Free Mission, and the Norwegian Pentecostal Mission (NPM), consolidated their work in Kenya to register the FPFK. The NPM contributed the term 'pentecostal', whereas the SFM contributed the term 'free' to form the Free Pentecostal Fellowship in Kenya (Anderson 1984:1).

The two missionary agencies were already in Kenya by the late 1950s, not long before the country had its independence in 1964.

Notable works have been written on the FPFK denomination (Joshua 2005). The FPFK Jubilee celebrations held at Thessalia on 28 October 2005 did not witness any publication apart from valuable speeches delivered by various representatives. ${ }^{1}$ In 2013, Taabco Consultancy firm did an evaluation work for FPFK and released a report (Taabco 2013:16). Various national FPFK projects have produced documentary reports that are archived at the FPFK head office in Nairobi. A 2015 national project managed from the general secretary's office by the name Inuka Kanisa ${ }^{2}$ had the objective of producing a history documentary on FPFK church activities. In 2016, the authors ${ }^{3}$ 1.For example, see John Kitur, FPFK celebrates its golden jubilee, the FPFK General Secretary's speech on 28 October 2005 at Thessalia Mission Centre, Report by FPFK General Secretary.

2 Inuka Kanisa is a Swahili word transliterated as 'Arise Church'. See AGM reports by FPFK, General Secretary, Walter Andhoga, 2015.

3.Liv Torrild was resourceful in accounting for Norwegian history, whereas Maud Anderson put together Swedish memories as the two ladies were already based in Scandinavia at the time of this research. These two ladies have served as missionaries in Kenya for quite a long time and were extremely resourceful. The author interviewed them several times.

Note: The collection entitled 'Christina Landman Festschrift', sub-edited by Wessel Bentley (University of South Africa) and Victor S. Molobi (University of South Africa). 
wrote a brief history of the Swedish section of the FPFK (Joshua, Mungai \& Musumba 2017:23-57). It is against this backdrop that the researcher set out to write a history of the Norwegian section of the FPC. The article is based on a twophased methodology. Firstly, an archival study that investigated collections of letters, reports, minutes, briefs and church legal documents found in the FPFK head office, and secondly, an oral study comprising 20 interviewees, purposefully sampled out of missionaries, early church evangelists and pastors, and current leaders at various levels.

During its AGM held in March 2015, a fierce contestation emerged between Scandinavian missionary representatives and local FPFK national board members over an ambitious expansion of FPFK's Kindaruma Guest House in Nairobi into an FPFK Premier Hotel with an estimated cost of about KES 400 million. Missionaries argued that FPFK had lost focus of evangelism and that it is now intending to spend more money in expanding its business interests. On the contrary, local church leadership argued that the organisation needs to invest to support evangelism now as there is no more support coming from Scandinavia. Local leadership had their way as missionary representatives vowed not to commit any of their funding to such engagements.

In this article, I shall argue that nationalisation of Nordic Pentecostal missionary establishments in Kenya, particularly the NPM, was a key turning point with far-reaching implications for the survival of the local churches. Driven by the decision of Nordic governments to channel development aid through missionary agencies as a response to 'UN Development Decade' as well as the agenda of national independence in Kenya, the nationalisation process has come to bear an identity crisis for the FPFK as heavily funded social projects coexist alongside stagnated church congregations. The contestation over the strategic focus for the church with regard to 'soul winning' versus 'social wellbeing' has led to further alienation of the local church from its mother bodies in Scandinavia.

It is important that I outline watershed years for the FPC as a background to the period under review. The earliest Norwegian Pentecostal missionary arrived in Kenya in 1955 (Arne 1974:1). The first joint FPFK AGM after the merger of Norwegian and Swedish missionary agencies was in $1984{ }^{4}$ and the first FPFK National Board constituting of local (Kenyan) leaders without missionaries was elected in 1997 (Taabco 2013:21). Therefore, the period between the onset of the first FPFK missionary to Kenya (1955) and the birth of FPFK as a merger product between Swedish and Norwegian missionaries' establishments (1984) is about 29 years. During this period, the missionaries worked independent of each other at mission field and almost entirely depended on their churches and agencies in Scandinavia. The period witnessed expansive church establishments in various regions. The article contests that during the period under review, the NPM was characterised by a fast-growing enthusiasm in establishing mission stations and local churches through evangelism and social work activities in education, medical care, orphanages, midwifery and compassionate handouts of commodities to villagers. These would be overtaken by the efforts to merge Swedish and Norwegian establishments into one denomination in 1976 and the move towards nationalising the FPFK by handing over church leadership to Kenyans by 1997.5

\section{The context of Pentecostal missionary activities in Kenya's church history}

Although the early history of mainline missionary Christianity in Kenya has attracted an overwhelming interest from scholars, considering works such as Rabai to Mumias: A Short History of the Church of the Province of Kenya, 1844-1994 (CPK 1994:1-35), A History of the Methodist Church in Kenya (Nthamburi 1982) and The Catholic Church in Kenya: A Centenary History (Baur \& Burgman 1990), it is not so for Pentecostals, especially Pentecostalism established by Western missionaries. A comprehensive history of early Pentecostalism in Kenya is lacking. This may be partly because of the fragmented nature of the movement itself. In attempting to locate the FPFK within that history, I found a close relation between the FPFK, the Full Gospel Churches of Kenya (FGCK) and the Pentecostal Assemblies of God (PAG). The earliest Pentecostal missionary to arrive in Kenya was a Finnish seaman, Emil Danielsson, in 1912 (Anderson 2004:220). He stayed in Africa for 7 years and returned after the First World War. In 1918, North Americans established work at Nyang'ori, western Kenya, which was later associated with Pentecostal Assemblies of Canada (PAOC) (Nyabwari \& Kagema 2014:27-33) and registered locally in 1965 as PAG (http://www.pewforum.org/2010/08/05/ historical-overview-of-pentecostalism-in-kenya/). The PAOC way of outreach was tremendously successful. It majored in health clinics, children schools and literatures. It is striking that when Finnish Pentecostal missionaries came back to Kenya after the Second World War, they not only used PAOC permits but were also motivated by its approach to missionary work. The sisters Alma and Eava Raatikainen and the married couple Paavo and Vieno Kusmin came under the umbrella of Finnish Free Foreign Mission (FFFM) and started working in Koru near Kisumu in 1949. It was Kusmin who, in turn, hosted the first FPFK missionaries, the couple Arvid and Gunborg Bustgård of the NPM in 1955, shortly before they established their work in Muhoroni.

During the 1930s, mainline missionaries, most notably the Presbyterian John Arthur, opposed female circumcision. As a result, freedom fighters, such as Jomo Kenyatta, supported the creation of indigenous churches some of which were distinctively Pentecostal such as African Independent Pentecostal Church of Africa (Joshua 2009:15-30). Meanwhile, the East African Revival reached Kenya in 1937 after spreading fast in Rwanda and Uganda. Timothy Morgan 5.Rev. Peter Odak, Interview by Rev. David Musumba, digital recording, at FPFK headquarters, Nairobi, 29 October 2014. 
rightly notes that it 'drew many protestants toward evangelical and Charismatic Christianity' (Morgan 2006:1-4). Locally known as tukutenderesa, the revival's ideals were further popularised by the preaching of American Evangelist Tommy Lee Osborn who promised 'full Gospel' with healing and a confrontation of witchcraft. Lounela (2007:88) rightly observed that Osborn's vision was 'an alternative to medical and other social work, especially during the period from his first crusade in 1957 to the end of the colonial period in Kenya in 1963'. He proclaimed that the unevangelised people needed preachers who confirmed their message with miracles.

After the national independence in 1963, Pentecostalism in Kenya grew rapidly. In 1967, an American Pentecostal preacher, Dale Brown, founded the Kenya Assemblies of God (KAG), which a survey in the early 1990s credited as Nairobi's fastest growing denomination with an annual growth rate of 38\% (Maxwell 2000). In 1970, Joe Kayo founded the Deliverance Church of Kenya, which attracted urban youth and by '1976 was an important member of the Evangelical Fellowship of Kenya (EFK)' (Anderson 2004:165). Between 1972 and 1986, the number of Pentecostal churches in the country doubled as its urban presence became increasingly characterised by Televangelism, prosperity theology and crusades by Western preachers (Ayieko \& Ombuor 2004). In 2003, Kenya's population was approximately $63 \%$ Protestants and 26\% Catholics (CBS, MOH \& ORC Macro 2003). The 2006 Pentecostal Forums' Survey indicated that renewalists including Charismatics and Pentecostals - accounted for more than half of Kenya's population.

The survey also found that approximately seven in 10 Protestants in Kenya are either Pentecostal or Charismatic, and about one-third of Kenyan Catholics surveyed can be classified as Charismatic. ${ }^{6}$

The relation between the Pentecostals and the Kenyan government has largely been shaped by ethnicity and the changing government regimes. During the colonial state period, Nordic and American missionaries were more trusting of the less interfering British rule in their advancement of the gospel. However, they did not enjoy such privileges as the Anglican Church of the Province of Kenya (ACK) did by then. During the early 1960s, missionaries feared that the imminent independence of Kenya would end their evangelism activities and appropriate them.

Lounela rightly noted that the Europeans and Americans had fresh in their memory what had happened in China at the end of the 1940s, when the Communists seized power and prohibited all missionary work' (Lounela 2007:22).

There was an amicable relationship between churches and the first independent government regime under President Jomo Kenyatta. Mainline churches, such as the Presbyterian and the Anglican, were largely headed by Kikuyu bishops, the same ethnic tribe as the president. In fact, the archbishop of Anglican Church was Kenyatta's brother-in-law (Fretson 2001:147). However, when Kenyatta died in 1978 and Daniel Arap Moi, who is from the Kalenjin tribe, took over, the relations changed drastically. Mainline churches under the umbrella of the National Council of Churches of Kenya (NCCK) mounted opposition to Moi on account of his one party politics. Key critical clerics here were Anglican bishops David Gitari, John Henry Okullu and Alexander Muge, along with the Presbyterian leader Timothy Njoya. In contrast, the EFK, whose membership comprised predominantly Pentecostal denominations, including the FPFK, and Kalenjin in ethnicity, openly supported Moi (Joshua \& Kapinde 2016:79-100). So severe was the rift between the council and the fellowship that in 1986, when the ruling party proposed to abolish the secret ballot and replace it with public 'queue' voting, Gitari's vocal anti-government stance prompted the remaining Pentecostals, including the Full Gospel Church, the United Pentecostal Church, the African Inland Church and the African Independent Pentecostal Church of Africa, to decamp and join the fellowship, which had adopted a rather silent stance (Anderson 2004:165).

The reign of President Mwai Kibaki came with the national constitution amendment where Pentecostals joined the 'Kenyan Church' in campaigning for a 'No Vote' on account of the inclusion of Muslim Kadhis Courts and its purported support for gay rights. Even after defeat, Pentecostal churches supported the opposition, whereas the mainline churches, especially the Roman Catholic Church, associated closely with the Catholic president.

The development of the FPFK in this rather ragged Kenyan context marks out certain unique features for the FPFK. Firstly, FPFK is one among the few mainstream Pentecostal Churches in Kenya that were founded by Western missionaries. This is a feature it closely shares with the FGCK, KAG and the PAG. Secondly, the FPFK is largely a rural or upcountry-based church as opposed to urban. This is largely a heritage from Scandinavian mission stations that were established among rural agrarian communities and have remained as such. As a matter of fact, farming was the business model of the founding missionaries and therefore conveniently the church has grown in semi-urban areas almost completely avoiding the large cities. Concerted efforts in the recent past to establish branches in urban areas have failed miserably. ${ }^{7}$ Thirdly, and of great significance to its historical development, FPFK was uniquely born out of Scandinavian missionaries' effort to cooperate and merge afield. Arguably, it is the only church born out of Western missionary merger in the region. The intended plan at the merger meetings of Roysambu in 1977 was to bring together all Nordic Pentecostal congregations, including those established by Danish, Swedish, Finnish and Norwegian missionaries. Indeed, many Scandinavian missionaries were 7.Rev. Walter Anthhoga, the FPFK General Secretary, digital recording, interview by author at FPFK headquarters in Nairobi on 14 December 2015. 
TABLE 1: Comparison of Free Pentecostal Fellowship in Kenya with early Pentecostal Churches in Kenya.

\begin{tabular}{|c|c|c|c|c|c|c|}
\hline Sr. no. & Name of denomination & Missionary society & Country of origin & Year of entry into Kenya & Bible college & Name of missionary \\
\hline 1 & $\begin{array}{l}\text { Free Pentecostal } \\
\text { Fellowship in Kenya }\end{array}$ & $\begin{array}{l}\text { Norwegian Pentecostal Mission } \\
\text { and Swedish Free Mission }\end{array}$ & $\begin{array}{l}\text { Norway and } \\
\text { Sweden }\end{array}$ & 1955 & $\begin{array}{l}\text { Karen Bible } \\
\text { College }\end{array}$ & $\begin{array}{l}\text { Arvid and Gunborg Bustgård Gustav } \\
\text { and Maria Struble }\end{array}$ \\
\hline 2 & $\begin{array}{l}\text { Pentecostal Assemblies } \\
\text { of God }\end{array}$ & $\begin{array}{l}\text { Pentecostal Assemblies of } \\
\text { Canada }\end{array}$ & Canada & 1918 & $\begin{array}{l}\text { Nyang'ori Bible } \\
\text { College }\end{array}$ & \\
\hline 3 & $\begin{array}{l}\text { Full Gospel Churches of } \\
\text { Kenya }\end{array}$ & Finish Free Foreign Mission & Finland & 1949 & $\begin{array}{l}\text { Koru Bible } \\
\text { College }\end{array}$ & $\begin{array}{l}\text { Emil Danielsson, Alma and } \\
\text { Eava Raatikainen, Paavo and } \\
\text { Vieno Kusmin }\end{array}$ \\
\hline 4 & Kenya Assemblies of God & American Assemblies of God & The United States & 1967 & & Dale Brown \\
\hline
\end{tabular}

vehemently opposed to the very idea of establishing churches, arguing that this would lead to too many Pentecostal denominations in the country. ${ }^{8}$ This Westerndriven merger, or so it was intended, has turned out to be the Achilles foot for the FPFK to date (Table 1).

The way in which Nordic missionary agencies related to mission field and pioneering churches back home was also unique as compared to the rest of Europe and North America. The SFM, NPM and FFFM did not have the responsibility of sending missionaries or even supporting their work at mission field in any way. They simply coordinated the missionary activities and let the mothering church congregations raise funds and send missionaries with specific objectives.

\section{Norwegian Pentecostal Mission in Kenya and the establishment of Thessalia mission station}

The early missionary activities of the NPM in Kenya are associated with a missionary couple by the name Arvid and Gunborg Bustgård who came from the Norwegian town of Fredrikstad where Arvid Bustgård owned and ran a bicycle shop. ${ }^{9}$ At the age of ' 46 years, he sold the shop and together with his wife they left for Kenya because they felt God's calling to do so'. ${ }^{10}$ They arrived in Mombasa in 1955 by ship in a trip that had taken a month around Africa through Atlantic and Indian oceans. Bustgård would fondly retell of how after arriving in Mombasa, which is actually a city in Kenya, he asked for direction to Kenya. ${ }^{11}$ While in Mombasa, they came into contact with another Norwegian missionary couple, Early and Walther Olsen. For a very short time, they stayed together with Olsens before they were picked by the Finish missionary called Kusminen and were taken to the mission station of the Native Finish Mission at Koru in Western Kenya. While in Koru, Kusminen taught Bustgård the Luo language because he was eloquent in it. ${ }^{12}$

8.Maud Anderson, interview by Stephen Muoki, digital recording, at FPFK headquarters in Nairobi on 07 December 2014

9.Liv Torrild, online correspondence with author, email and attachments, 13 February 2015.

10.Rev. Paul Ocholla, digital recording, interview by David Musumba at FPFK Head Office in Nairobi on 13 November 2014.

11.See footnote 8 .

12.Focus Group Discussion, digital recording, involving 18 African retired clerics of the Norwegian Department of FPFK, held at FPFK-Kindaruma Guesthouse in Nairobi on 12 and 13 November 2014.
Because there was no registered Norwegian mission in Kenya at the time, Arvid and Gunborg Bustgaad came in as visitors with the Finish Free Foreign Mission (FFFM) hosted by Kusminen. They stayed with them for about a month. It was common for missionaries from different mission agencies to assist each other in this way.

Interestingly, Kusminen had been similarly assisted by PAOC missionaries who had established themselves in Nyang'ori, Western Kenya, in 1918 (Nyabwari \& Kagema 2014:27-33).

Their church was locally registered in 1965 as PAG. ${ }^{13}$ It is striking that when the Finish sisters, Alma and Eava Raatikainen, and the married Finish missionary couple, Paavo and Vieno Kusminen, came under the umbrella of FFFM and started working in Koru near Kisumu in 1949, just after the Second World War, they not only used PAOC permits but were also motivated by its approach to missionary work. ${ }^{14}$

While Bustgård was staying with the Finish missionary, he was informed that there was a lady who had a farm called Thessalia, which she had bought from a Greek farmer. Thessalia is a Greek name transliterated as Thessalonica in the English Bible. Bustgård met the lady and negotiated to buy the land at a cost of Kshs 30000 . The size of the land was 118 acres (Joshua 2006:173-191).

The lady was Mrs Janssen, an American widow, whose husband was a missionary sent by the Lutheran mission. She had run the mission station, Thessalia, for 2 years together with her husband Mr Janssen. At the time she met Bustgård she was already widowed. Her husband died in 1954. She felt unable to run the mission alone and had been praying for someone to come and take over the place and the work.

Thessalia mission centre, as it is called today under the ownership of FPFK, is situated at the border between the land of the Luo and the Kipsigis tribe. Mrs Janssen saw the Bustgård couple as God sent and she sold Thessalia to them in 1955.

Missionary Bustgård immediately started evangelical work and built a church made of mud and grass. He registered as a missionary of the NPM in $1956 .{ }^{15}$ Most missionaries who

13.See http:// www.pewforum.org/2010/08/05/historical-overview-of-pentecostalismin-kenya

14.See footnote 8.

15.See footnote 11 . 
joined him thereafter lived in mud and grass-thatched houses. Bustgårds saw immediately that there was a need for educating children as there were no schools around. He built the first school with mud and roofed it with iron sheets. He started to ask Norwegians to support the children with a 100 NOK per year for a child. He invited children to school, but observed that the people around Thessalia removed children's lower teeth, something that negatively affected their education because of the illness and the trauma that went with it. The Luo removed six teeth and the Kipsigis two. He told the parents not to remove children's teeth if they wanted to get school fees as well as support for their children.

Although Bustgård registered his work as the NPM in Kenya, he received very little support from Norway at the beginning. To be able to raise funds for construction and mission work, he resorted to business enterprises. ${ }^{16}$ He took a contract to harvest trees at Thessalia farm that he sold as firewood to the Uganda Sugar Company, now known as Muhoroni Sugar Company. ${ }^{17} \mathrm{He}$ also tendered to provide grass to a tea company in Kericho. The grass was used for roofing workers' houses in the tea farms. He also raised some layers of chicken out of which he got eggs that he would sell to Asians in Kisumu. Bustgård's background as a businessman showed off in the way he managed to support missionary endeavours financially developing Thessalia mission from a humble beginning of mud-thatched houses to the modern buildings seen today. ${ }^{18}$

\section{Early Indigenous Kenyan Evangelists and Pastors in the Norwegian Pentecostal Mission activities}

It was not easy for Bustgård to raise local evangelists and workers in the new mission. He brought several evangelists from the FFFM to assist him in missionary work. Firstly, he brought $\mathrm{Mr}$ and Mrs Albert Oriare Kitaga. ${ }^{19} \mathrm{He}$ also brought William Chan, Luke Obiero, Mama Dorcas-Mama Kanisa and $\mathrm{Mr}$ and Mrs Flora Cheqe from the same mission. Bustgård also got Joel Osoro, who was a pastor with PAG in Muhoroni. Joel Osoro became the first pastor of the Muhoroni Church, ${ }^{20}$ and he was later transferred to Thessalia Church, although the first pastor of Thessalia was Albert Oriare who in 1962 was sent to Ahero after he had pastored for 8 years. Therefore, Bustgård worked with four key native church leaders in the early years. These were Pastor Joshua Arap Kiplangat, who pioneered work in Kalenjin land together with evangelist William Chan. Albert Oriare was in charge of Kisumu and Joel Osoro worked in Thessalia. Afterwards, they were joined by others such as Silas Owiti and Joel Osoro, who were the first pastors in the Muhoroni Church. The first native Kipsigis was Joshua Arap Kiplangat who pastored the Chepsirian Church. $^{21}$

\section{See footnote 8 .}

17.See footnote 9 .

18.See footnote 9 .

19.See footnote 8 .

20.Rev. Francis Nyagenke, digital recording, interview by author at the FPFK Head Office on 14 November 2014.

21.See footnote 18

\section{Missionary activity through health care}

The first missionaries to join Bustgård from Norway were nurses. Olaug Stenersby came to Thessalia in 1957 and Kari Enger arrived in 1960. They started a dispensary where they could assist the pregnant women and provide medical services to the community in Muhoroni. The next missionaries who came were Åse and Bjarne Lind. They arrived with their five boys in August 1963. In 1964, Inger and Gudbrand Sandvold came to help in the development of Thessalia. Missionaries Egil and Gudrun Gjervoldstad together with their three children arrived in 1965; they were also placed at Thessalia. Miriam Johansen who came the same year was also situated at Thessalia. She assisted Bustgård with bookkeeping. Sister Miriam had a special interest in helping suffering children and she later established the home for orphans in Thessalia. ${ }^{22}$

The health work needed more nurses, and in 1969 the nurse Åse Høydahl arrived to serve in the Thessalia dispensary. In 1970, nurse and midwife Nora Tjervaag joined to assist as well. As the maternity ward needed personnel on a 24-h basis, more midwives were needed, and in 1971 nurse and midwife Norun Sjøli arrived for the maternity unit. In 1976, Laila Tjore and May Kristine Aamli, both trained in nursing and midwifery, arrived in Thessalia to work within the health sector. $^{23}$

\section{Missionary activity through the establishment of Norwegian education}

As the number of Norwegian children increased, there was a need for a Norwegian school and a teacher. The mission board in Norway advertised a schoolteacher position and eventually sent Astrid and Arne Tveter in 1966. Astrid started school for the Norwegian kids in a small office at the church building within the Thessalia mission centre.

In 1973, a new school building for Norwegian missionary kids was built at Thessalia. This came as a much needed relief to Mrs Astrid Tveter who until then had run the school in the veranda at her home at Nyambare Hill. Now a nice new building with adequate premises was available for the pupils and a boarding facility was also constructed. This was aided by a change in the education policy in Norway where the government could approve schools abroad and grant funds for their running. Alf and Astrid Somdal were the new teachers entrusted with the task of running the new school. The first boarding parents were Trygve and Karin Korneliussen. This was really a milestone for the Norwegian mission in Kenya and even Norwegian children of parents working with the Norwegian Official Development Aid, NORAD, joined the school. In the same year, Inger and Øyvind Johansen became new teachers at the school. In 1978, Torunn and Ragnar Bakken took over as teachers in the Norwegian school after Inger and Øyvind 22.See footnote 8

23. See footnote 8 
Johansen, while Inger and Torolf Karlsen had the responsibility for the Norwegian boarding. ${ }^{24}$

In 1979, Gunnveig and Ernst Knudsen with their two children took on as missionaries with duties within an evangelical ministry and later on this was combined with the task of being boarding parents for the Norwegian missionary kids. In 1980, Liv Toril Rinding took over after Bakkens as the responsible teacher at the Norwegian school. ${ }^{25}$ In addition, she was involved in an evangelical ministry in the churches and also preaching in prisons in the area. The teacher Liv Bergh arrived at Thessalia in 1981 to work in the Norwegian school.

\section{Availability and accessibility of the Bible in local languages}

Kristine Sjøli who had come to Tanzania as a NPMs missionary in 1958 moved to Thessalia together with the Swedish missionary Karin Larsson. These two were dedicated to distribute Bibles and Christian literature. They used to go to the market place to sell Christian literature and slowly they engaged faithful Christians who assisted them in selling Bibles in the different local languages out in the district. This method of evangelism was neither new to the African church nor to the missionary. Gosnell Yorke in a journal article entitled 'Bible translation in Anglophone Africa and her diaspora: A postcolonialist agenda' rightly argued that the entire translation and distribution of Bible in local African languages, as spearheaded by the United Bible Society (Yorke 2004):

[I]s an integral part of a much larger whole ... has a long and strong tradition in Africa going back to the inter-testamental translation in Alexandria, Egypt, of the Hebrew Bible and other cognate writings into Hellenistic Greek, the lingua franca of the day ... followed by the subsequent proliferation of translation into various indigenous African languages especially in the wake of the missionary movement of the late eighteenth century and extending to the present. (pp. 153-166)

Hence, the translation and distribution of Christian materials, including the Bible itself, were, to a large extent, ideologically driven. In a similar line of thinking, Kinyua (2013:58-95) critiques that the missionary emphasis on the vernacular in Bible translation during the colonial Africa, though in most cases defended as a neutral, legitimate and benevolent act of redemption, actually disguised the colonial power situation to the extent that even when Bible translators aimed at dominating and restructuring the colonised's view of reality, the translation process was not in itself immune to the restructuring power of decolonisation.

Norwegian missionary work on Christian literature was more concerned with the provision of access rather than actual translation on account of language barrier. By and large, the agenda of the coloniser became interwoven into the

24.See footnote 8

25.See footnote 8 .
Christian Gospel message through the written medium and the social gospel. A good case in point was the work of caring for destitute children, orphans and handicapped children. Miriam Johansen had a special call for helping the suffering children. In 1982, a new building was established at Thessalia for the specific purpose of caring for children in need. Berit Sjursen was to be engaged in this work too. ${ }^{26}$

\section{Expansion of Norwegian Pentecostal Mission's work to other parts of Kenya}

During the late 1960s, the Norwegian missionary work expanded exponentially. The Thessalia mission station's work that had started in 1955 expanded to a great extent. Every year hundreds of people were baptised.

Between January and June 1966, a total of 700 people were baptised. On one occasion, 178 persons were baptised at the Thessalia mission. ${ }^{27}$ On 02 April 1967, 278 new Christians were baptised.

Among them was the sub-chief of Kiptere, an indicator that time for outward expansion had come. Following Charismatic preaching of Albert Oriare in 1963, Michael Onyango, the present Bishop of Likoni in Mombasa, was converted and was immediately absorbed into the ministry starting as a Sunday schoolteacher at the Thessalia mission. ${ }^{28}$

This growth necessitated deeper and a more organised ministry training for African ministers. It also called for more workmanship. As a result, a Bible school was started to train NPM African ministers. The courses were short and focussed on simple ministerial skills such as evangelism, pneumatology, preaching, pastoral ministry, church administration and Bible interpretation (exegesis and hermeneutics). ${ }^{29}$ The first Bible school class took off in 1967 at the Thessalia mission and consisted of Michael Onyango, John Oloo, Henry Olwayo, Naftali Ogogo, Leornard Nyaoke, Ezekiel Oloo, Noah Ohulo, Lukas Choge, Christopher Langat, John Oloo, Wiliam Ofwete, Christopher Opiyo, George Odawo and Eliud Onyango. In 1968, Arthur Nyborg Pettersen was sent from Norway to Thessalia to help in teaching at the Bible school. Michael Onyango recalled how these first students became influential in church work. ${ }^{30}$ He regretted that many were no longer alive and that a few, such as Eliud Onyango, left the faith and ministry and now serves as a traditional healer. Nevertheless, the majority have established and pastored great churches in various parts of the country. ${ }^{31}$

26.See footnote 8 .

27.Bishop Michael Onyango, digital recording, interview by author at FPFK Head Office on 12 November 2014.

28.See footnote 9

29. Rev. Timothy Nyakundi, digital recording, interview by author at FPFK Head Office on 12 November 2014.

30.See footnote 25 .

31.Rev. Joel Bii, digital recording, interview by author at FPFK Head Office on 12 November 2014. 


\section{Kiptere mission station (1956)}

Kiptere was the second NPM mission station after Thessalia that came up in 1956. Following the conversion of a chief, the Chepsirian Church was established through the preaching of William Chan and Lukas Chege. In 1958, the Kaitui branch was set up under the leadership of Joshua Kiplangat. The Cheramor branch was started in 1962, Chepsoo in 1966 and Koibono in 1971. By 1984, Kiptere area had many new churches, including Mbogo Valley, Iraa, Sosiot and Kaitui. ${ }^{32}$ African ministers, such as Solomon Rotich, Samuel Langat, Daniel Ngeno and Joseph Ngeny, were church administrators fully in control in these areas. ${ }^{33}$

Under the leadership of missionary Bjorn Lind, the Kiptere mission station was built in 1970. In 1978, Åse and Bjorn Lind had returned to Kenya after some years in Norway. They stayed at Nyambare Hill until when they took on the task of setting up the buildings for a polytechnic school at Kiptere in $1982 .{ }^{34}$ A man by the name Francis Wambwaya, commonly nicknamed as 'the building missionary', was identified by Bustgård as having a special skill in construction. ${ }^{35} \mathrm{He}$ was in charge of almost all the constructions under the NPM, especially the missionary houses. He had accepted the Christian faith and was converted through prayers by Pastor Osoro. In Kiptere, Wambwaya was instrumental in building a Bible Course Center, a Polytechnic institute, and Kaliyet and Kesinet primary schools. ${ }^{36}$

\section{Nyambare hill mission in Kisiiland (1963)}

Norwegian Pentecostal Mission work in Nyambare started with a small church at a place called Hawinga in 1963. Anglican and Roman Catholic churches already had a presence in the region when a young preacher, John Ochola, preached and converted Chief Habbakuk Obwanda together with his many wives on 22 December 1962. ${ }^{37}$ The following Sunday, they cleared a bush under a tree and started their first service. Ochola brought the news to Bustgård who was hesitant to take up the work because of the long distance between the two stations. Pastor Osoro was for the idea and soon the chief offered land for the church in Nyambare. ${ }^{38}$

It was not until 1965 when a group of missionaries led by Bjarne Lind agreed to go westward to Usonga in Siaya district and explore what this native preacher, John Paul Ochola, was doing. On 15 August 1965, Bjarne Lind and some others went to Usonga to have a look at the plot that had been offered 32.Rev. Gabriel Ouma, digital recording, interview by author at FPFK Head Office on
12 November 2014 .

33.See footnote 27.

34.See footnote 29

35.Mr Francis Wambwaya, digital recording, interview by author at FPFK Head Office on 12 November 2014.

36.See footnote 33 .

37.Pastor John Oloo and Mary Onyango, digital recording, interview by author at FPFK Head Office on 12 November 2014.

38.See footnote 27 for mission work. ${ }^{39}$ They decided to start mission work at Usonga and on 22 February 1966, the building work started. Through preaching of evangelist Astariko Okwero on 10 April 1966, George Christopher Opiyo, his wife and many others converted. The first baptism was held on 26 June 1966 at Goro in River Nzoia. ${ }^{40}$ Abednego Odongo became the first pastor of the church and Astariko was the evangelist. During the official opening of the church building in June 1966, Norwegian missionaries 'gave out blankets and the church denomination acquired its local Swahili nickname, Dini Mablanket, rendered as denomination of blankets' ${ }^{41}$ When missionaries opened the first school in January 1967, a rumour spread among the community warning 'that the white men were sucking people's bloods'. ${ }^{42}$ However, after Mr Solomon Ndondi took over as the first African teacher, 'people changed their minds'. The first building to be erected was the school building. By 1968, clinic and maternity services had started. The first two nurses and midwives at Nyambare Hill were Tora Brynhildsen and Oddrun Nordås. Both sister Tora and sister Oddrun arrived in $1967 .{ }^{43}$ Their care for the sick and for the pregnant women was a big relief for the people in the area. ${ }^{4}$

The Nyambare Church grew fast during the late 1960s. The first children to be dedicated in Nyambare were Florence Lorna Opiyo and George Onyango, whereas the first wedding to be solemnised was that of George Ohanga and Claris Obiero on 18 September $1967 . .^{45}$ Other branches in the region included Luhano, which was opened in 1965, and Bondo Kolalo, which was pioneered and pastored by Ochola in 1966. Ochola used to earn a salary of 120 Kenyan Shillings and had a congregation of 35 persons. ${ }^{46}$

During the years 1970-1971, several missionaries were welcomed to Kenya. The families of Tveter and Gjervoldstad had moved to Nyambare Hill to take care of the missionary work there, while Åse and Bjarne Lind went to Norway on a vacation. New missionaries to Thessalia were now Trygve and Karin Korneliussen with their three children and Gunnar and Hanne Østrem with their five boys. Hanne and Gunnar came from Tanzania where they had stayed for 1 year. In 1973, Liv Toril and Arne Rinding came for missionary ministry and were placed at Nyambare Hill to fill the vacancy after Hanne and Gunnar Østrem. The same year Ruth Skoglund arrived, and she was also placed at Nyambare Hill to serve in the evangelical ministry. The nurse Jorunn Fagerheim also arrived in Kenya in 1974 to assist in the dispensary at Nyambare Hill. However, in 1975, missionary 39. See footnote 35 . 40.See footnote 27 .

41.Focus Group Discussion held with 20 NPM church leaders at Kindaruma Guest House in Nairobi on 14 November 2014.

42.See footnote 18 .

43.See footnote 8 .

44.See footnote 11 .

45.See footnote 27

46.See footnote 35 . 
Arne Rinding suddenly took taken ill and died after a short illness. Oddrun and Ola Emil Sprakehaug with their children arrived in August 1975 to take over after Rinding at Nyambare Hill. ${ }^{47}$

In 1973, there was an expansion within the health department too. Norwegian Official Development Aid had opened up to grant more development aid funds through Christian mission organisations, which facilitated the expansion of the maternity buildings at Thessalia and the appointment of more health personnel. In 1974, three more midwives arrived in Thessalia to work in the maternity ward. These three were Åse Dagsvik, Solveig Granseth and Aud Seterøy. Arthur and Elly Nyborg Pettersen were the first Norwegian missionaries to take up work in Nairobi. They found it to be cumbersome to reach out to the underprivileged people with the gospel like those staying in the Mathare Valley slum.

\section{Lwala Church and the Oyugis mission station (1965)}

Zacharia Asiyo and Benson Bwala started a church at Lwala in $1965 .{ }^{48}$ With the support of the Thessalia mission, the church grew and more branches were established in the Oyugis region. These included Wangedongo Church under the leadership of Hezron Kongo and Joseph Nyakaka. ${ }^{49}$ Missionary Karen Larson and Christian Sijole were very supportive of the work. Fredrick Aoro gave land for the church and the Oyugis Church was started in 1971. Bjarne Sivertsen had arrived in 1980 and he also was placed at Thessalia..$^{50}$ In 1981, the nurse Jorunn Slettum arrived as well as Berit Sjursen. Jorunn Slettum started health work at Oyugis where Franck Haukeland had built a dispensary and two houses where missionaries could stay. Later on in 1982, Jorunn Slettum and Bjarne Sivertsen married and together they ministered at Thessalia as boarding parents for the Norwegian school children for a year. In 1984, they were back in Kenya and were placed at Oyugis in 1985 after a short period at Nyambare. ${ }^{51}$

\section{Eastleigh Church and Karen Bible School in Nairobi (1973)}

In 1973, Nyborg Pettersen founded a congregation in Eastleigh, a suburb on the eastern side of Nairobi city. In the same year, Signe and Frank Ove Haukeland with their children came to assist in the ministry in Eastleigh. In 1974, a new church building was set up. The church building was inaugurated in $1975 .^{52}$

Meanwhile, a Bible school at Karen, a southern suburb of Nairobi, was being constructed. It was officially opened

47. See footnote 11 .

48.See footnote 18 .

49.See footnote 27

50.See footnote 25 .

51.See footnote 8 .

52.See footnote 25 in 1976..$^{53}$ Gudbrand Sandvold was appointed as the first principal of the Bible school. ${ }^{54}$ Torolf and Inger Karlsen were appointed to take over as principal and matron at the Karen Bible School in 1981 (Table 2).

In 1982, the Norwegian mission organisations together became receivers of funds collected through a TV programme called 'Action Hope'. These funds were spent as the mission's share when projects from NORAD were applied for. This led to considerable social activity. Numerous schools were built, many of them in Kisii in addition to the Kiptere Polytechnic. At Ober Kamoth, a health centre was set up. Birger and Anne Grete Hovden had arrived in 1981, and Birger an experienced engineer was responsible for completing the Ober Kamoth construction work. ${ }^{55}$

Ola-Emil and Oddrun Sprakehaug came for their second period in August 1981. They took over the responsibility for the evangelistic ministry in Kisii after Trygve Korneliussen who together with his wife Karin went to Norway for furlough in spring 1981. In 1982, Inger and Øyvind Johansen returned back to the Norwegian school to take over the responsibility after Liv Toril Rinding departed as principal. Jorunn and Bjarne Sivertsen were appointed as boarding parents. In 1983, Margrethe and Svein Nystrøm came to Kenya for their first period. They were placed at Nyambare Hill. ${ }^{56}$ In the years to come, an extension of the ministry out from Nyambare Hill would take place. An evangelistic ministry was started at Namatore, halfway between Eldoret and Kitale.

In the year 1981, 545 faithful were baptised at Thessalia and 900 at Nyambare Hill. ${ }^{57}$ And in 1983, there were 6585 Christians within the churches attached to the Nyambare Hill mission. The work expanded to new areas like Oyugis, Kiptere, Kisii and Nairobi. And all the time new evangelists were engaged and the gospel was preached across villages. ${ }^{58}$ Missionaries were continuously engaged in constructing new churches, and church inaugurations occurred several times a year. In Norway, the mission in Kenya had faithful supporters who collected money both for paying the evangelists and the building of churches. Helping the poor children had become an important matter, and the education of hundreds of children was sponsored.

\section{Conclusion}

I find that documenting a rather recent history such as that of the NPM is challenging because most of the resource persons are still very emotionally attached to the experiences and memories either as former missionaries themselves, children

53.Mr Wambwaya, digital recording, interview by author at FPFK Head Office on 12 November 2014

54.See footnote 29 .

55.See footnote 8 .

56.See footnote 11 .

57.Norwegian Pentecostal Mission in Kenya, AGM minutes of a meeting held in Thessalia Mission Centre on 12 April 1982.

58.See footnote 27 
TABLE 2: Chronological development of Norwegian Pentecostal Mission missionary establishments in Kenya.

\begin{tabular}{|c|c|c|c|}
\hline $\begin{array}{l}\text { Year of } \\
\text { establishment }\end{array}$ & Name of the church & African pastor or evangelist & Norwegian missionary \\
\hline 1955 & Thessalia & $\begin{array}{l}\text { Mr and Mrs Albert Oriare Kitaga } \\
\text { Luke Obiero, Mama Dorcas (Mama Kanisa) }\end{array}$ & Arvid and Gunborg Bustgård \\
\hline 1958 & Muhoroni-Kisumu & Joel Osoro, Albert Oriare & \\
\hline 1963 & Usonga, Hawinga-Nyambare mission & John Paul Ochola & $\begin{array}{l}\text { Bjarne Lind, Tora Brynhildsen, Oddrun Nordås, } \\
\text { Liv Toril and Arne Rinding, Hanne and Gunnar } \\
\varnothing \text { strem }\end{array}$ \\
\hline 1965 & $\begin{array}{l}\text { Kiobonyo-Nyamokenye and Nyamira } \\
\text { mission centre (1986) }\end{array}$ & Hezron Oyaro, Paul Nyangau, Nyagenge & Sprouke, Trygve Korneliussen \\
\hline 1965 & Lwala - Oyugis mission (1984) & Zacharia Asiyo, Benson & Karen Larson and Christina Sijole Franck Auckland \\
\hline 1965 & Segere & John Oloo & \\
\hline 1966 & Kitale-Sio Port & $\begin{array}{l}\text { Busembewilliamofwetesimeonmzee, bukomavincentokuro, } \\
\text { mudembi Joseph Ogesa, Masiro Katienostephen Hono }\end{array}$ & Svyein Nysterom \\
\hline 1972 & Nyalenya & Simon Mzee & \\
\hline 1972 & Opando & Gordon Ooko & \\
\hline 1985 & Tuigoin & Gabriel Ouma & \\
\hline
\end{tabular}

of the missionaries or part of the African clerics who worked with the missionaries. Perspectives as to how NPM negotiated through controversies and challenges are interwoven with the concern by many interviewees to provide 'a good story to be told to future generations ${ }^{\prime 59}$ as well as a few others who insist on some of the not so good memories as a fact that needs to be told as well. ${ }^{60}$ This contrast is well depicted in the distinction between duties of European missionaries and those of African pastors and evangelists in a colonial Kenyan context.

During a Focus Group Discussion with a group of retired evangelists and pastors who worked with the NPM missionaries, it became apparent that the African clerics worked under certain difficult restrictions. They recalled that 'missionaries never allowed black ministers to enter their houses and they did not teach the people to give for the mission work'. Congregations were discouraged from giving any alms or money to the African pastors and evangelists because the missionary claimed that they were fully sponsored and paid. In what they described as 'spiritual colonialism', the clerics observed that they 'were not allowed to stay at homes, go for a leave or own any business enterprise ${ }^{6}{ }^{61}$ The missionaries relied on rumours from members as opposed to reports from the pastors and would make abrupt visits to congregations. The missionaries never involved the pastors and evangelists in decision-making, missionary wives would instead decide and the missionary would say the committee has decided. John Osoro noted that 'Lind was a very angry person and when you crossed his line he would take his gun and ... you had to run for your life many times' ${ }^{6}{ }^{62}$ These experiences have to be realised within the context of colonialism that was evident in the entire country during the period under review (Joshua \& Kapinde 2016:79-100).

59.See footnote 8.

60.See footnote 11 .

61.See footnote 11

62.Rev. John Osoro, digital recording, interview by author at Kindaruma Quest House in Nairobi on 14 November 2014.
I also found that there were other factors, apart from spiritual, that motivated the increase of NPM missionaries to Kenya during the late 1960s and 1970s. Firstly, the policy of the Scandinavian governments to channel development funds through non-government organisations in 1960 created a new situation in the mission agencies. This was in response to the declaration by the United Nations that the 1960s would be a UN development decade (Freston 2001). It was usual for the colonial powers to support the social work of the mission agencies active in their colonies (FPFK 1997), but the Norwegian mission agencies were not used to receiving support from their own government for work in Africa. The government aid then effected some anticipated, and some unexpected, changes in the work and organisation of the mission agencies in the home country and in the mission field, hence the increase in social work activities, monies and Norwegian missionaries to Kenya that already had a bilateral agreement with Norway (Freston 2001).

Secondly, in the early 1960s, the imminent independence of Kenya urged missionaries to speed up their evangelisation work. The colonial period in Africa was drawing to a close and as Lounela (2007) rightly noted:

[T] he Europeans and Americans had fresh in their memory what had happened in China at the end of the 1940s, when the Communists had seized power and prohibited all missionary work. (p. 22)

The missionaries feared that the time of evangelism would soon be over in Kenya too. Therefore, the urgency of the Norwegian missionaries to build schools, hospitals and orphanages was only an immediate means to the greater end, to spread the full gospel 'while it was day' (Nyabwari \& Kagema 2014:27-33).

Thirdly, there was an increasing good will between the Norwegian government and, by extension, the NPM, with the Kenyan colonial government. During the colonial state period, Nordic missionaries were more trusting of the less interfering British rule in their advancement of the gospel. However, they did not enjoy such privileges as the ACK did 
(Lounela 2007:22). This was in contrast to neighbouring Tanzania where because of German land policies and the First and Second World Wars, missionaries were swiftly transferring to Kenya and other African countries.

\section{Acknowledgements}

The author thanks the Free Pentecostal Church in Kenya and its partners in Scandinavia for assisting immensely in the data acquisition process.

\section{Competing interests}

The author declares that they have no financial or personal relationships which may have inappropriately influenced them in writing this article.

\section{Author's contributions}

S.M.J. is the sole author of this article.

\section{Ethical considerations}

The rights of all informants were well considered and documented through signed informed consent forms.

\section{Funding information}

This research was partly funded by the Free Pentecostal Church in Kenya.

\section{Data availability statement}

Data sharing is not applicable to this article as no new data were created or analysed in this study.

\section{Disclaimer}

The views and opinions expressed in this article are those of the authors and do not necessarily reflect the official policy or position of any affiliated agency of the authors.

\section{References}

Anderson, A., 2004, An introduction to Pentecostalism: Global charismatic Christianity, Cambridge University Press, Cambridge.

Anderson, M., 1984, Notification of dissolution by general Secretary of Evangelical Free Mission in Kenya, Free Pentecostal Fellowship in Kenya, Nairobi.
Arne, P., 1974, Secretary of the Swedish Free Mission (Stockholm) letter to Registrar of Title, on 28th March, Free Pentecostal Fellowship in Kenya, Nairobi.

Ayieko, F. \& Ombuor, J., 2004, 'Making money in God's name', The Nation, 11 June, p. 2.

Baur, J. \&Burgman, H., 1990, The Catholic Church in Kenya: A Centenary History St. Paul Publications-Africa, Nairobi.

Central Bureau of Statistics (CBS), Ministry of Health (MOH) \& ORC Macro, 2004, Kenyan Demographic and Health Survey, CBS, MOH \& ORC Macro, Calverton, MD.

Church of the Province of Kenya, 1994, Rabai to Mumias: A short history of the Church of the Province of Kenya, 1844-1994, Uzima Press, Nairobi.

Free Pentecostal Fellowship in Kenya (FPFK), 1984, Minutes of the Annual Genera Minutes of the Free Pentecostal Fellowship, FPFK, Nairobi.

Free Pentecostal Fellowship in Kenya (FPFK), 1997, Minutes of the Annual Genera Meeting of the Free Pentecostal Church, FPFK, Nairobi.

Free Pentecostal Fellowship in Kenya (FPFK), 2002, Constitution of the FPFK, Free Pentecostal Fellowship in Kenya, Nairobi.

Free Pentecostal Fellowship in Kenya (FPFK), 2013, Assessment report by Taabco, Orbit, Nairobi.

Free Pentecostal Fellowship in Kenya (FPFK), 2018, Minutes of the Annual Genera Meeting, FPFK, Nairobi.

Freston, P., 2001, Evangelicals and politics in Asia, Africa and Latin America, Cambridge University Press, Cambridge.

Joshua, S.M., 2005, 'Towards contextualization of Evangelical Theological education: A case especially for the Free Pentecostal Fellowship in Kenya', MA thesis, Africa Nazarene University.

Joshua, S.M., 2006, 'The interface between "Missionary" and "National" Theological education in the free Pentecostal fellowship in Kenya: A historical perspective', Studia Historiae Ecclesiasticae XXXII(3), 173-191.

Joshua, S.M., 2009, 'The Church and the 1929 Female Genital Mutilation (FGM) contestation in Kenya, with special reference to the Scottish Presbyterian Church and the Kikuyu community', Studia Historiae Ecclesiasticae XXXV(1), 15-30. https://doi.org/10.17159/2309-8392/2016/v61n2a4

Joshua, S.M. \& Kapinde, S.A., 2016, "'Pulpit Power" and the unrelenting voice of Archbishop David Gitari in the democratisation of Kenya, 1986 to $1999^{\prime}$, Historia 61(2), 79.

Joshua, S.M., Mungai, E. \&Musumba, D., 2017, 'The Swedish Free Mission (SFM) Work in Kenya between 1960 and 1984', Studia Historiae Ecclesiasticae 43(1), 23-57. https://doi.org/10.17159/2412-4265/2016/828

Kinyua, K., 2013, 'A postcolonial analysis of Bible translation and its effectiveness in shaping and enhancing the discourse of Colonialism and the discourse of resistance', Black Theology 11(1), 58-95. https://doi.org/10.1179/17431670X1 resistance, Black

Kitur, J., 2005, FPFK celebrates its golden jubilee, Free Pentecostal Fellowship in Kenya, Nairobi.

Lounela, J., 2007, Mission and development: Finnish Pentecostal, Lutheran and Orthodox Mission agencies in Development Work in Kenya 1948-1989, ABO Academic University Press, Pargas.

Maxwell, D., 2000, 'African gifts of the spirit: Fundamentalism and the rise of the bornagain movement in Africa', in M. Percy (ed.), Fundamentalism, church and society, pp. 45-71, SPCK, London.

Morgan, T., 2006, 'Africa's Azusa Street', Christianity Today, 28 March, pp. 23-40.

Nthamburi, Z.J., 1982, A history of the Methodist Church in Kenya, Uzima Press, Nairobi.

Numbers, Facts and Trends Shaping Your World, viewed 13 August 2017, from http:// www. pewforum.org/2010/08/05/historical-overview-of-pentecostalism-inkenya/.

Nyabwari, B.G. \& Kagema, D.N., 2014, 'Charismatic Pentecostal Churches in Kenya: Growth, culture and orality', International Journal of Humanities Social Sciences and Education 1(3), 27-33.

Yorke, G., 2004, 'Bible translation in Anglophone Africa and her Diaspora: A postcolonialist agenda', Black Theology 2(2), 153-166. https://doi.org/10.1558/ blth.2.2.153.36034 